\title{
Characterization of Clays from the "Sè" Region in the South of Benin Used to Make Ceramic Water Filters
}

\author{
Akuemaho Virgile Onésime Akowanou ${ }^{1}$, Martin Pépin Aina ${ }^{1}$, \\ Sènandémi Edwige Reine Mahunon ${ }^{1}$, Benjamin Kouassi Yao ${ }^{2}$ \\ ${ }^{1}$ Laboratory of Water Sciences and Technics, University of Abomey-Calavi, Abomey-Calavi, Republic of Benin \\ ${ }^{2}$ Laboratory of Industrial Processess, Synthesis, Environment and New Energies, Félix Houphouët-Boigny National Institute, Yamoussoukro, \\ Ivory Coast
}

\section{Email address:}

virgile.akowanou@yahoo.fr (A. V. O. Akowanou), mahunonqueeen@yahoo.fr (S. E. R. Mahunon), marnickson@yahoo.fr (M. P. Aina), beyao@yahoo.fr (B. K. Yao)

${ }^{*}$ Corresponding author

\section{To cite this article:}

Akuemaho Virgile Onésime Akowanou, Martin Pépin Aina, Sènandémi Edwige Reine Mahunon, Benjamin Kouassi Yao. Characterization of Clays from the "Sè" Region in the South of Benin Used to Make Ceramic Water Filters. American Journal of Applied Chemistry.

Vol. 5, No. 6, 2017, pp. 90-95. doi: 10.11648/j.ajac.20170506.11

Received: October 22, 2017; Accepted: November 1, 2017; Published: November 24, 2017

\begin{abstract}
Clay materials have been used for centuries by local populations in ceramic pottery. This research aimed to examine natural clay as raw material for the manufacturing of ceramic pot filters. Thus, three clay samples were collected from a quarry in "Sè", located in the southwestern part of the Benin Republic. All the samples were characterized using granulometric analysis, X-ray Powder Diffraction (XRD), loss on ignition (LOI), cation exchange capacity (CEC), and measurement of Atterberg's limits. $\mathrm{N}_{2}$ adsorption technique were used to define specific surface areas and the major elements composing the clays were determined. The chemical and mineralogical analysis indicates that all of the samples contain various amounts of quartz and kaolinite, followed by muscovite and vermiculite. They also indicate that the clay materials are silico-aluminous clays. CEC and $\mathrm{N}_{2}$ adsorption showed as expected a low CEC and specific surface because of the presence of quartz and kaolinite quartz. The analyzed samples reveal that clays are very plastic, with an organic matter content ranging from $7.8 \%$ to $9.8 \%$ (loss on ignition). TGA analysis showed that the suitable sintering temperatures is from $700^{\circ} \mathrm{C}$ and above. Based on their mineral composition and physical properties, the clays are suitable as raw material for ceramic industry, especially for ceramic water filters.
\end{abstract}

Keywords: Clay, Ceramic, Potential Utilization, Characterization, Sè

\section{Introduction}

Today, clay minerals have a wide application due to their specific physic-chemical properties, such as their surface areas, ion exchange capacities and cation adsorption properties [1, 2, 3, 4, 5].

Kaolinitic clays are significant industrial raw materials used in various manufacturing applications, especially in ceramics processing [6]. Because of its dehydroxylated form (metakaolin), which is very reactive [7], a strong interest in kaolin has recently been developed in traditional ceramics.

Clay minerals are generally used in a large number of applications, such as ceramics, rubber and porcelain manufacturing, chemical, paper adsorbents etc.). Among them, clay-based ceramic water filters (CWFs) are one of the more promising technologies for household water treatment. Ceramic water filters are used as a low-cost method to improve drinking water quality at the point of use, in order to produce safe drinking water $[8,9,10,11]$. They are produced mixing of clay with burn-out material (sawdust, rice husk....) and water. To make ceramic filters it is essential to find an appropriate clay deposit.

In Benin Republic, few studies have been carried out on the use of clay as raw material for traditional ceramic manufacturing. In Sè, a village located in the department of Mono, in the southwestern part of the country (Figure 1), 
clay materials are exploited by the local populations to make traditional ceramic. This activity is mainly carried out by women who have a secular experience in the field. In Sè as in many other regions in the country clay materials are also applied in construction (bricks, roofing or walls).

The present study was carried out in order to characterize samples collected from a natural clay deposit from Sè. The clay samples were characterized after sampling to determine their quality for use as a low-cost material. Although the use of raw clay for traditional ceramic making has a long history in the community, its use for further potential industrial ceramic applications requires a better knowledge of the raw material.

\section{Materials and Methods}

\subsection{Sample Preparation}

The geology of Sè (Figure 1) consists in a coastal sedimentary basin which is formed by Cretaceous-Tertiary series made up of clays, sand, gravel, ferruginous sandstone overlain by clayey sands and fluviatile deposits [12]. The study focused on the characterization of three samples named A1, A2 and A3 (Figure 2). These clay samples are those used by the local population for ceramics. The precise location of the site (N06 29'35.64" and E0147'37.38") was determined in the field using a hand-held GPS device (Garmin 60). The samples were taken at three different depths corresponding to three horizons: horizon 1 (A1): having an average thickness of $105 \mathrm{~cm}$ recognizable by its blackish color and situated after a layer of vegetable soil (50 cm thickness);

horizon 2 (A2): having an average thickness of $45 \mathrm{~cm}$, recognizable by its reddish color;

horizon 3 (A3): located on the bottom of $\mathrm{A} 2$.

In order to ensure a representative sample obtained by quartering, no $<50 \mathrm{~kg}$ of clays were collected. After extraction, they were dried at $105^{\circ} \mathrm{C}$ until constant weight was obtained, and then crushed and sieved to obtain the desired fraction $(<100 \mu \mathrm{m})$.

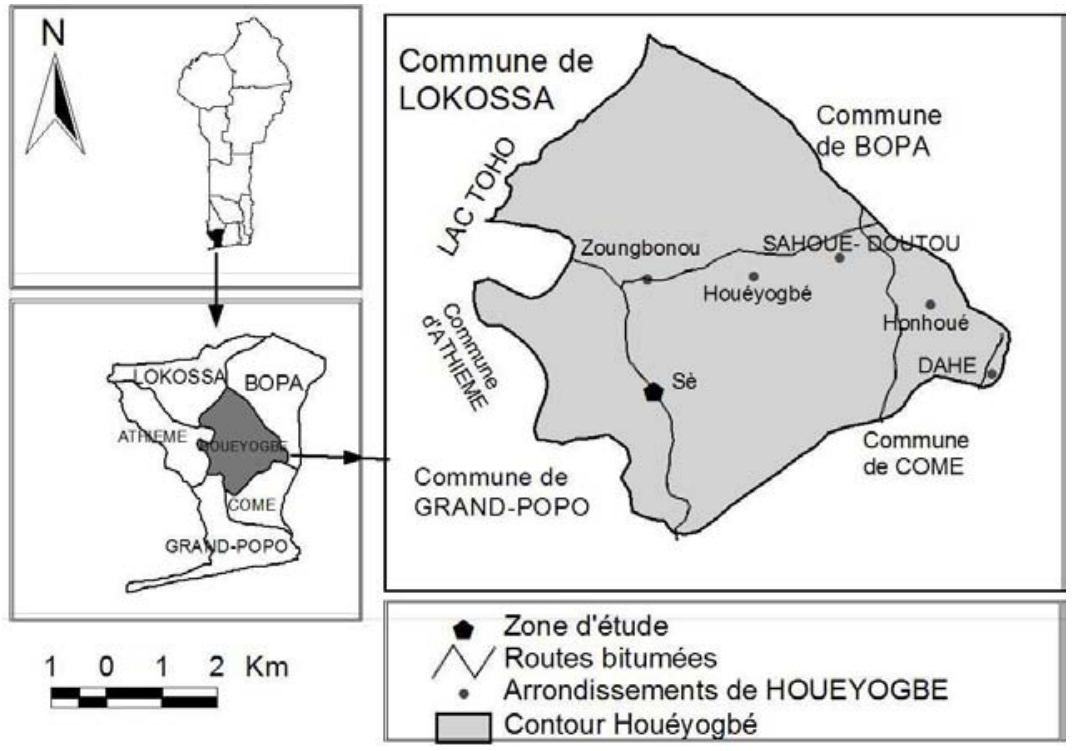

Figure 1. The geographic location of the studied sector.

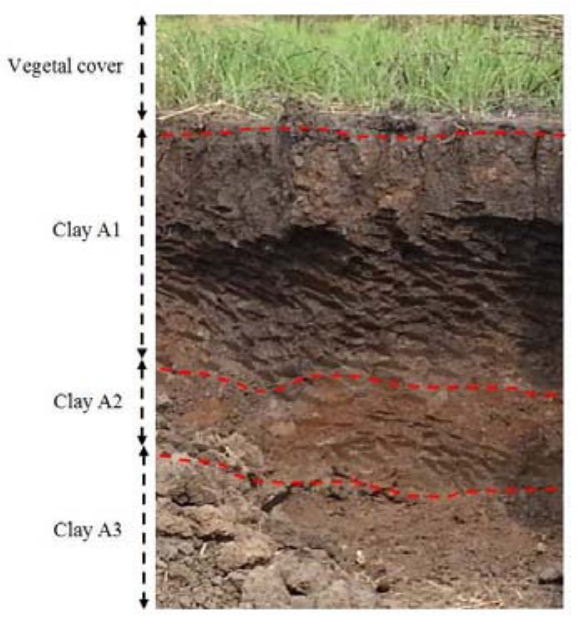

Figure 2. Study site profile.

\subsection{Methods}

The samples were subjected to granulometric analysis, $\mathrm{X}$ ray powder diffraction (XRD), determination of the composition of major elements, loss on ignition (LOI), cation exchange capacity (CEC), $\mathrm{N}_{2}$ adsorption technique to define specific surface area, measurement of Atterberg's limits.

Granulometric analysis was determined by sedimentometry according to the French standard NF 94-093.

XRD was conducted on the samples using a RigakuMiniflex II (Japan) with $\mathrm{CuK} \alpha$ radiation $(1,5405 \AA)$. The accelerating voltage and filament current were maintained at $30 \mathrm{kV}$ and $15 \mathrm{~mA}$, respectively. Samples were analyzed at $0.02^{\circ}$ step with a counting time of $2 \mathrm{~s} / \mathrm{step}$ from $5^{\circ}$ to $70^{\circ} 2 \theta$. All the diffractograms obtained were semi-quantitatively evaluated (relative abundances expressed in\%) employing the 
intensity ratio method. The major element compositions $\left(\mathrm{SiO}_{2}, \quad \mathrm{Al}_{2} \mathrm{O}_{3}, \quad \mathrm{Fe}_{2} \mathrm{O}_{3}, \quad \mathrm{~K}_{2} \mathrm{O}, \mathrm{MgO}\right)$ were deduced by calculation from the proportion of each major oxide.

LOI was measured from the total weight after ignition at $550^{\circ} \mathrm{C}$ for $2 \mathrm{~h}$. It was performed using a Keramikos oven.

The cation exchange capacity was measured with the standard methylene blue index procedure [13].

The gas adsorption technique defines specific surface area, size and distribution of solid material pores. The amount of gas needed to form a monolayer on a solid surface can be determined from the measurement of the volume of gas absorbed when pressure is increased in small doses at a constant temperature [14]. These analyses were performed using a BET Micromeritics ASAP 2020 V3.00 E equipment.

The plasticity parameters (liquid limit (LL), plastic limit (PL) and plastic index (PI) were determined by the Casagrande method in accordance with the French Standard NF P 94-051.

The thermal gravimetric analyses (TGA) were obtained with a SETARAM type 124.

\section{Results and Discussion}

\subsection{Particles Size Distribution}

The particle size distributions (PSDs) of the raw clays A1, $\mathrm{A} 2$ and $\mathrm{A} 3$ are shown in table 1 . The PSDs indicate the presence of three main fractions: (1) clay fraction $(<2 \mu \mathrm{m})$, (2) silt fraction, known for its particle size ranging between 2 and $50 \mu \mathrm{m}$, and (3) the remaining fraction coarser than 50 $\mu \mathrm{m}$. The clay fraction represented $28 \%, 55 \%$ and $28 \%$ of the A1, A2 and A3 clays respectively. The silt fraction represented $18 \%, 7 \%$ and $9 \%$ of the $\mathrm{A} 1, \mathrm{~A} 2$ and $\mathrm{A} 3$ clays respectively. The coarse portion represented $54 \%, 38 \%$ and $63 \%$ of the A1, A2 and A3 clays, respectively.

Table 1. Particles size distribution of the samples.

\begin{tabular}{lllll}
\hline Samples & & A1 & A2 & A3 \\
\hline Analyses & & & & \\
& Fraction $<2 \mu \mathrm{m}(\%)$ & 28 & 55 & 28 \\
Granulometry $(\%)$ & Limons $(2-50 \mu \mathrm{m})$ & 18 & 7 & 9 \\
& Sable $(>50 \mu \mathrm{m})$ & 54 & 38 & 63 \\
\hline
\end{tabular}

\subsection{Mineralogy}

The mineralogy of the samples was investigated using powder X-ray diffraction (Figure 3). For all of the natural clay samples, XRD revealed the presence of quartz $(53.8 \%$, $54.9 \%$, and $50.4 \%$ of $\mathrm{A} 1, \mathrm{~A} 2$ and $\mathrm{A} 3$ clays respectively) and kaolinite $(31.0 \%, 20.6 \%$ and $34.9 \%$ of $\mathrm{A} 1, \mathrm{~A} 2$ and $\mathrm{A} 3$ respectively) in various amounts. Moreover, muscovite represents about $14.2 \%, 23.8 \%$ and $14.0 \%$ of $\mathrm{A} 1, \mathrm{~A} 2$ and $\mathrm{A} 3$ respectively while vermiculite was present in traces (Table 2). The proportion of high kaolinite in comparison with the other elements present is of great interest, because among the minerals of clay raw materials, kaolinite remains one of the most frequently used and desired for the manufacture of ceramics. Quartz is always associated with kaolinite. And the high proportion of quartz is explained by the fact that the analyses were carried out on the clay material sieved at 100 $\mu \mathrm{m}$ and not on the "clay" fraction $(<2 \mu \mathrm{m})$.

Table 2. Mineralogy of the samples.

\begin{tabular}{lllll}
\hline Samples & & A1 & A2 & A3 \\
\hline & Quartz & 53.8 & 54.9 & 50.4 \\
Mineralogy (\%) & Kaolinite & 31.0 & 20.6 & 34.9 \\
& Muscovite & 14.2 & 23.8 & 14.0 \\
& Vermiculite & 1.1 & 0.7 & 0.7 \\
\hline
\end{tabular}

\subsection{Chemical Composition}

The chemical composition of the clays investigated is presented in Table 3. The main oxides were as expected $\mathrm{SiO}_{2}$ (74.58\%, 75.98\% and $73.49 \%$ for A1, A2 and A3, respectively) and $\mathrm{Al}_{2} \mathrm{O}_{3}(15.25 \%, 13.00 \%$ and $16.66 \%$ for $\mathrm{A} 1, \mathrm{~A} 2$ and $\mathrm{A} 3$ respectively), whereas $\mathrm{Fe}_{2} \mathrm{O}_{3}, \mathrm{~K}_{2} \mathrm{O}$ and $\mathrm{MgO}$ were present only in small amounts. All the samples contain more than $50 \%$ of $\mathrm{SiO}_{2}$ and have $\mathrm{Al}_{2} \mathrm{O}_{3}$ contents between $13 \%$ and $16.66 \%$. Based on mineral contents, the investigated clay samples can be classified into the group of silico-aluminous clays with a predominance of $\mathrm{SiO}_{2}$.

For all samples, the loss on ignition was between $7.8 \%$ and $9.9 \%$. These high loss-to-fire values can be explained by the fact that samples contain a significant proportion of kaolinite (the kaolinite loss on fire is $14 \%$ ). The same applies to the high content of $\mathrm{Al}_{2} \mathrm{O}_{3}$ ( $40 \%$ for kaolinite).

Table 3. Chemical composition of the samples.

\begin{tabular}{lllll}
\hline Samples & & $\mathbf{A 1}$ & $\mathbf{A 2}$ & $\mathbf{A 3}$ \\
\hline & $\mathrm{SiO}_{2}$ & 74.58 & 75.98 & 73.49 \\
& $\mathrm{Al}_{2} \mathrm{O}_{3}$ & 15.25 & 13.00 & 16.66 \\
Chemical & $\mathrm{Fe}_{2} \mathrm{O}_{3}$ & 0.09 & 0.04 & 0.04 \\
composition (\%) & $\mathrm{K}_{2} \mathrm{O}$ & 1.31 & 0.06 & 0.06 \\
& $\mathrm{MgO}$ & 0.23 & 0.15 & 0.14 \\
& $\mathrm{LOI}$ & 8.3 & 7.8 & 9.9 \\
\hline
\end{tabular}

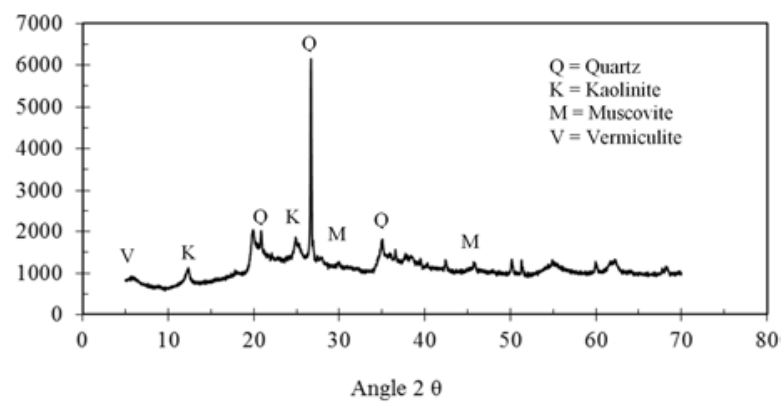

(A1)

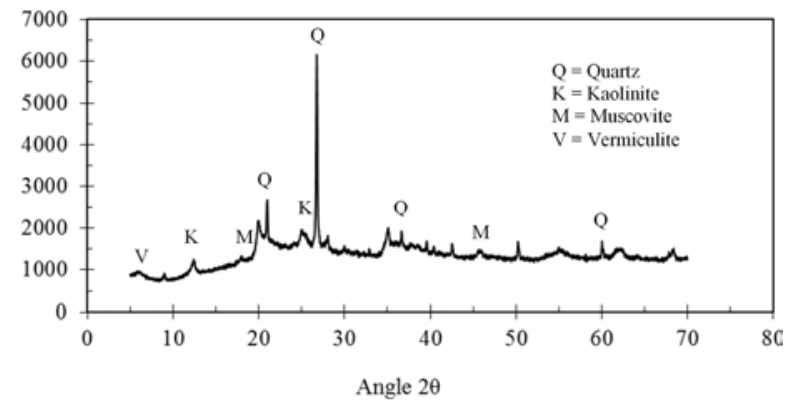

(A2) 


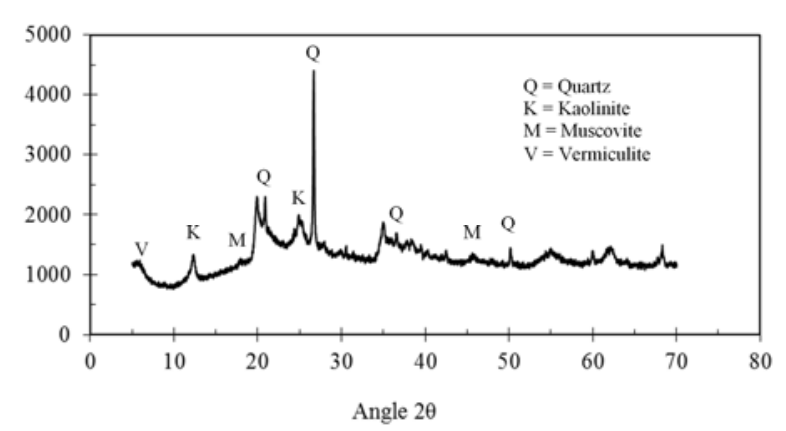

(A3)

Figure 3. XRD spectrum of clay samples.

\subsection{Thermogravimetry Analysis}

The thermogravimetric results are reported in Figure 4. Three weight loss areas were observed for the raw materials. The first weight loss was due essentially to the evaporation of the physisorbed water. The second started at about $400^{\circ} \mathrm{C}$ and ended at about $600^{\circ} \mathrm{C}$. It corresponds to the phenomenon of dehydroxylation which marks the transformation of the kaolin into metakaolin according to the equation [15]:

$$
\mathrm{Al}_{2} \mathrm{Si}_{2} \mathrm{O}_{5}(\mathrm{OH})_{4} \stackrel{550^{\circ} \mathrm{C}}{\longrightarrow} \mathrm{Al}_{2} \mathrm{O}_{3}+2 \mathrm{SiO}_{2}+2 \mathrm{H}_{2} \mathrm{O}
$$

It should also be noted that at about $350^{\circ} \mathrm{C}$ the combustion of the organic matter present in the clay materials began. After $600^{\circ} \mathrm{C}$, there is a slight loss of mass up to $700^{\circ} \mathrm{C}$, then a stabilization of the graph. It was concluded that sintering temperature greater than $700^{\circ} \mathrm{C}$ is suitable for ceramic application because of the formation of metakaolin [7].

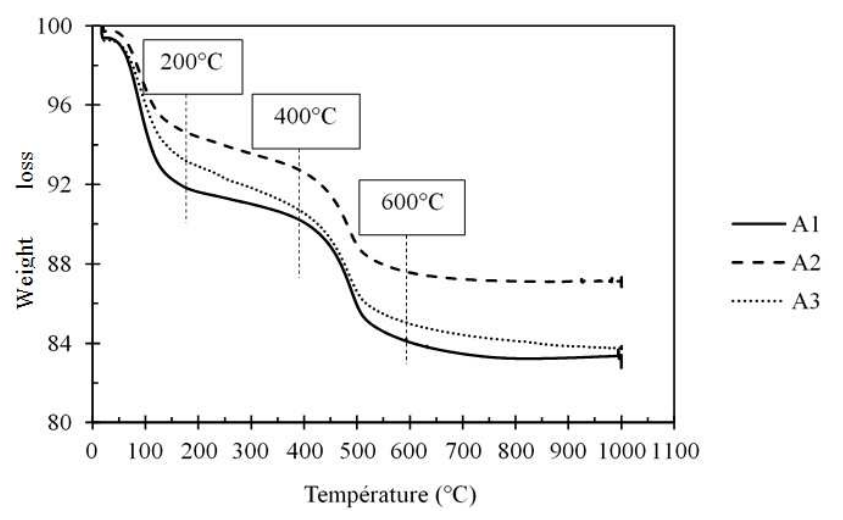

Figure 4. Thermograms curves (TGA) of raw clays (A1, A2 and A3).

\section{5. $\mathrm{N}_{2}$ Adsorption and Cation Exchange Capacity}

Nitrogen adsorption-desorption isotherms recorded on the clay materials A1, A2 and A3 are presented in Figure 5. For the three clay materials, isotherms were of type IV, with an H4 type hysteresis loop in accordance with the International Union of Pure and Applied Chemistry (IUPAC) classification [14]. Type IV isotherm is characteristic of porous adsorbents having pore sizes in the range of $15-100 \AA$ [14]. In addition, the $\mathrm{H} 4$ type hysteresis loop is encountered for solids having narrow pore size distributions. The specific surface area $\left(\mathrm{S}_{0}\right)$, the surface area of the micropores (Smic) and the external surface area (Sext) were determined from these isotherms by applying the BET equation at $\mathrm{P} / \mathrm{P} 0=0.20$. Similarly, the total pore volume $(\mathrm{Vp})$, the volume of the micropores (Vmic) and the pore size (D) from the adsorption-desorption isotherms of $\mathrm{N}_{2}$ were determined according to the BJH methods. These different results are presented in Table 4. Overall, the specific surface area and CEC vary between $69.64-86.60 \mathrm{~m}^{2} / \mathrm{g}$ and $22.94-25.89 \mathrm{meq} / 100 \mathrm{~g}$ of air-dried clay, respectively. These low values are explained by the presence of impurities (carbonates, quartz) in these clays and the abundance of minerals formed by kaolinite [16]. Although vermiculite is a clay having a large specific surface area, its quantity was quite small.
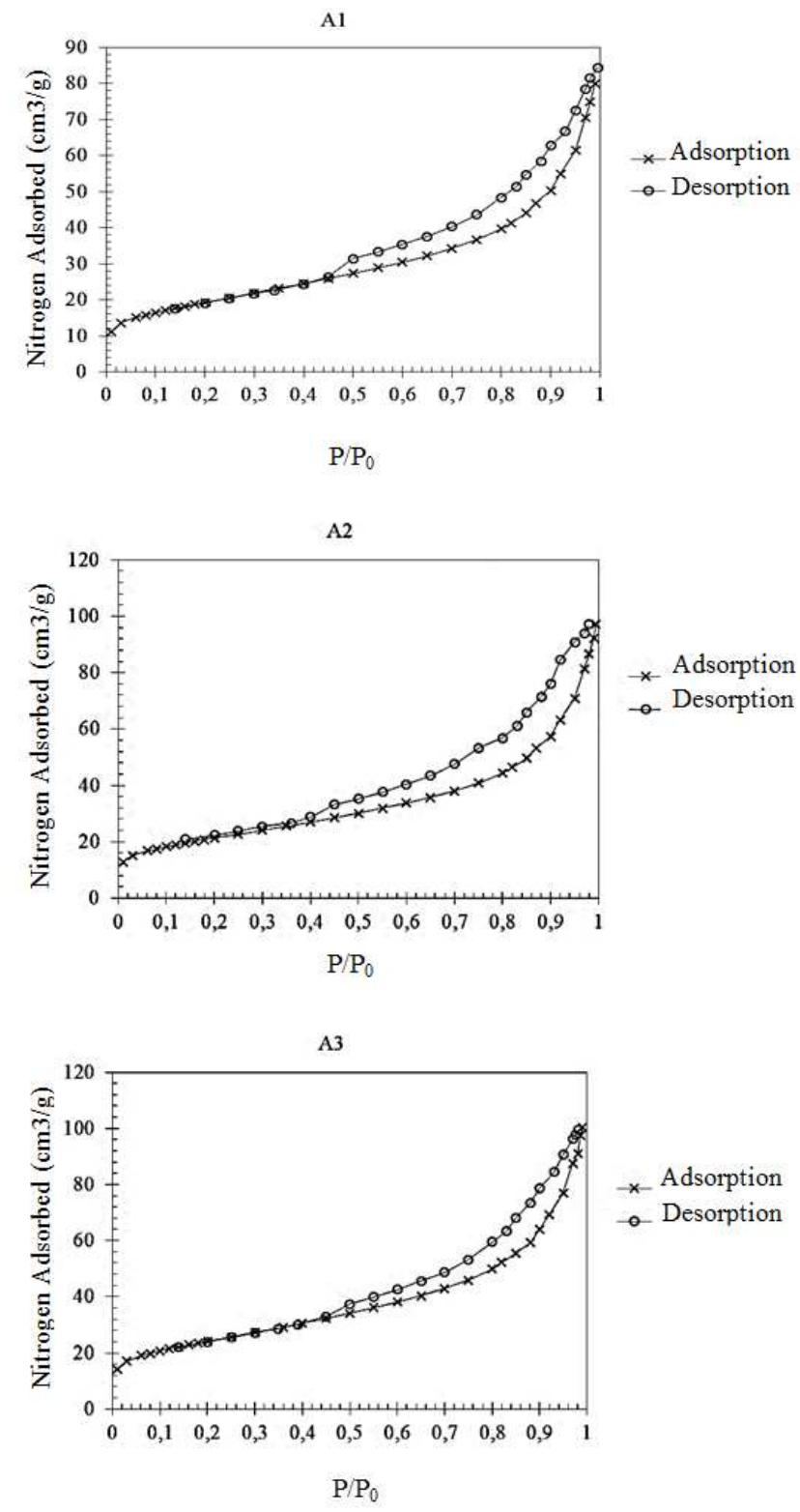

Figure 5. Nitrogen adsorption and desorption isotherms. 
Table 4. $\mathrm{N}_{2}$ adsorption and CEC of the samples.

\begin{tabular}{lllll}
\hline Samples & & A1 & A2 & A3 \\
\hline Cation exchange capacity (CEC) (meq/100g of air-dried clay) & & 25.89 & 22.94 & 25.65 \\
& Specific surface S. S. $\left(\mathrm{m}^{2} / \mathrm{g}\right)$ & 69.64 & 76.47 & 86.60 \\
& Surface of micropores Smic $\left(\mathrm{m}^{2} / \mathrm{g}\right)$ & 5.94 & 8.17 & 10.73 \\
$\mathrm{~N}_{2}$ adsorption - BET & External surface Sext $\left(\mathrm{m}^{2} / \mathrm{g}\right)$ & 63.69 & 68.30 & 75.87 \\
& Total pore volume $\mathrm{Vp}\left(\mathrm{cm}^{3} / \mathrm{g}\right)$ & 0.11 & 0.13 & 0.14 \\
& Volume of micropore Vmic $\left(\mathrm{cm}^{3} / \mathrm{g}\right)$ & 0.002 & 0.003 & 0.004 \\
& Pore size D $(\AA)$ & 62.63 & 65.93 & 62.49 \\
\hline
\end{tabular}

\subsection{Atterberg's Limits}

The plasticity parameters of the studied clays are illustrated in Table 5 and show that the liquid limit varies between 80.4 and $87.8 \%$. The plastic limit oscillated between $30.0 \%$ and $34.2 \%$. These parameters, according to casagrande indicate that these clays belong to kaolinite clays having high plasticity [17]. According to the bibliography, there is not necessarily a direct link between the values obtained for the Atterberg's boundaries of a clay material and its other characteristics [18]. The mineralogical characteristics of the clay materials could nevertheless explain the values obtained for the Atterberg's limits. Indeed, depending on the charge density of the exchangeable cations which provide hydrophilic sites for solvent sorption [19], several layers of water can be incorporated between the low phyllosilicate sheets. Then, the amount of water that can be absorbed is much lower [20]. [21] observed a direct relationship between the Atterberg's limits and the specific surface area. It should be noted that the great plasticity noted in the clay materials used is favorable to the extrusion and the use of ceramic paste. Moreover, this high plasticity is also favorable to shrinkage after drying and sintering. High shrinkage after drying and sintering are often the cause of cracks in the manufacture of ceramic products. Nevertheless, the addition of burn-out material (rice hulls and sawdust) during the manufacture of filters will reduce this plasticity of the raw material.

Table 5. Atterberg's limits of the samples.

\begin{tabular}{lllll}
\hline Samples & & A1 & A2 & A3 \\
\hline \multirow{3}{*}{ Plasticity (\%) } & Liquidity limit (LL) & 82.6 & 80.4 & 87.8 \\
& Plasticity limit (PL) & 34.2 & 30.0 & 31.6 \\
& Plasticity index (PI) & 48.4 & 50.4 & 56.2 \\
\hline
\end{tabular}

\section{Conclusion}

The properties of clay materials depend on their chemical and mineralogical compositions. The characteristics of these materials make their use possible, helping to foresee important potential properties. These characterization tests show that these materials:

Contain high proportions of sand, which implies a pretreatment in order to reduce this fraction before any exploitation;

Are very plastic, that is advantageous with regard to their malleability, but also disadvantageous since they are predisposed to cracking during drying and sintering withdrawals.

Contain organic matter $(7.8 \%$ to $9.8 \%$ for loss on ignition), this organic material having to be eliminated if the objective during the exploitation of these materials is to produce industrial ceramic products or ultrafiltration membranes etc.

Consist of kaolinite, muscovite and vermiculite;

Have suitable sintering temperatures greater than $700^{\circ} \mathrm{C}$; In view of the results of the TGA, it is appropriate during the heat treatment program to ensure the slow removal of the hygroscopic water and of the organic matter before applying higher heating rates, in order to avoid the cracking of the elaborated ceramic products.

In view of the results obtained, it appeared that the clay materials taken from the Sè quarry and studied are of particular interest for ceramic applications. They could, therefore, be used as raw materials to develop ceramic filters and in general, ceramic materials.

\section{References}

[1] O. P. Aghamelu, and C. O. Okogbue, "Characterization of some clays from Nigeria for their use in drilling mud," Appl. Clay Sci., vol. 116-117, pp. 158-166, 2015.

[2] P. Sooksaen, and S. Karawatthanaworrakul, "The properties of Southern Thailand clay-based porous ceramics fabricated from different pore size templates," Appl. Clay Sci., vol. 104, pp. 295-302, 2015.

[3] J. Jalali, M. Balghouthi, and H. Ezzaouia, "Characterization of porous clay ceramics used to remove salt from the saline soils," Appl. Clay Sci., 2016, in press.

[4] Z. Zhu, Z. Wei, W. Sun, J. Hou, B. He, and Y. Dong, "Costeffective utilization of mineral-based raw materials for preparation of porous mullite ceramic membranes via in-situ method," Appl. Clay Sci., vol. 120, pp. 135-141, 2016.

[5] S. Ummartyotin, N. Bunnak, and H. Manuspiya, "A comprehensive review on modified clay based composite for energy based materials," Renew. Sustain. Energy Rev., vol 61, pp. 466-472, 2016.

[6] J. Zhou, X. Zhang, Y. Wang, A. Larbot, and X. Hu, Elaboration and characterization of turbular macroporous ceramic support for membranes from kaolin and dolomite. J. Porous Mater., vol 17, pp. 1-9, 2010.

[7] A. Gharzouni, B. Samet, S. Baklouti, E. Joussein, and S. Rossignol, "Addition of low reactive clay into metakaolinbased geopolymer formulation: synthesis, existence domains and properties," Powder Technol., vol 288, pp. 212-220, 2016. 
[8] H. van der Laan, D. van Halem, P. W. M. H. Smeets, A. I. A. Soppe, J. Kroesbergen, G. Wubbels, J. Nederstigt, I. Gensburger, and S. G. J. Heijman, "Bacteria and virus removal effectiveness of ceramic pot filters with different silver applications in a long term experiment," Water Res., vol 51, pp. 47-54, 2014.

[9] J. Mellor, L. Adebe, B. Ehdaie, R. Dillingham, and J. Smith, "Modeling the sustainability of a ceramic water filter intervention,” Water Res., vol 49, pp. 286-299, 2014.

[10] A. I. A. Soppe, S. G. J. Heijman, I. Genburger, A. Shantz, D. van Halem, J. Kroesbergen, G. H. Wubbels, and P. W. M. H. Smeets, "Critical parameters in the production of ceramic pot filters for household water treatment in developing countries," J. Water Health., vol 13, pp. 587-599, 2015.

[11] A. Pérrez-Vidal, J. Diaz-Gomez, J. Castellanos-Rozo, and O. L. Usaquen-Perilla, "Long-term evaluation of the performance of four point-of-use water filters," Water Res., vol 98, pp. 176$182,2016$.

[12] P. Faure, and B. Volkoff, "Some factors affecting regional differentiation of the soils in the Republic of Benin (West Africa)," Catena, vol 32, pp. 281-306, 1998.

[13] P. T. Hang, and G; W. Brindley, "Methylene blue absorption by clay minerals. Determination of surface areas and cation exchange capacities," Clays Clay Miner, vol 18, pp. 203-212, 1970.

[14] K. S. W. Sing, D. H. Everett, R. A. Pierotti, J. Rouquérol, and T. Siemieniewska, "Reporting physiosorption data for gas/solid systems with special reference to the determination of surface area and porosity," Int. unon pure Appl. Chem., vol 57, pp. 603-619, 1985.

[15] M. Abubakar, M. Nasir, M. Aziz M. B. Uday, N. Ahmad and D. Mullite, "Preparation and characterization of a Nigerian mesoporous clay-based membrane for uranium removal from underground water," Ceram. Int., vol 42, pp. 8212-8220, 2016.

[16] S. Mahmoudi, A. Bennour, A. Meguebli, E. Srasra and F. Zargouni, "Characterization and traditional ceramic application of clays from Douiret region in South Tunisia," Appl. Clay Sci., vol 127-128, pp. 78-87.

[17] A. Sdiri, I. Ben, L. Ben, S. Bouaziz, and J. Duplay, "Geological and technological characterization of the Late Jurrassic-Early Creataceous clay deposits (Jebel Ammar, northeastern Tunisia) for ceramic industry," J. African Earth Sci., vol 129, pp. 282-290, 2017.

[18] S. Stanchi, M. d'Amico, E. Zanini, and M. Freppaz, "Liquid and plastic limits of mountain soils as a function of the soil and horizon type," Catena, vol 135, pp. 114-121, 2015.

[19] R. A. Schoonheydt, and C. T. Johnston, "Surface and interface chemistry of clay minerals," Dev. Clay Sci, vol 1, pp. 87-113, 2006.

[20] I. I. Topeshta, T. A. Sokolova, E. Bonifacio, and G. Falcone, "Pedogenic chlorites in podzolic soils with different intensities of hydromorphism: origin, properties, and conditions of their formation," Eurasian Soil Sci, vol 43, pp. 777-787, 2010.

[21] B. Dolinar, "A simplified method for determining the external specific surface area of non-swelling fine-grained soils," Appl. Clay Sci, vol 64, pp. 34-37, 2012. 